of historical contingency, as Stephen Jay Gould calls it (chance to the rest of us), to preposterous limits. If only, they suggest, Victoria's haemophiliac son Leopold had fallen down the stairs and died a few months earlier, then his son, Charles Edward, would not have been born. Hitler would then have lost an influential supporter and 30 million people would have been spared. They even suggest this happy outcome if Charles Edward had inherited his father's lethal gene. Wrong again. Sons inherit their single $\mathrm{X}$ chromosome from their mothers, so it would have been quite impossible for Leopold to have passed the haemophilia gene to his son. The only remotely persuasive historical consequence of the gene was the part it played in the rise of Rasputin to a position of influence in the Russian royal family. His hypnotic powers, so we are told, could alleviate the painful symptoms of the young Tsarevich Alexei, something the court physicians had failed to do.

As in The Quest for Anastasia, there is very little genetics in this book and even what there is is tinged with the depressingly negative view of humanity in general and monarchies in particular that drips from the pages. Even the five lines devoted to Watson and Crick's discovery of the structure of DNA wastes one of them by telling us they worked "in temporary accommodation".

It is a pity that the authors' account of their detailed work on this most famous of genes has been spoiled by carelessness, inaccuracies and distortions (the UK Forensic Science Service, for example, is based in Aldermaston, not Amersham). Although these infelicities may go unnoticed by the intended general readership, they do nothing to promote a real appreciation of genetics.

Bryan Sykes is at the Institute of Molecular Medicine, University of Oxford, John Radcliffe Hospital, Headington, Oxford OX3 9DU, UK.

\title{
Putting the peas in context
}

\section{Peter J. Bowler}

Gregor Mendel: The First Geneticist. By Vitezslav Orel. Oxford University Press: 1995. Pp. 353. £25.

MENDEL may be unique in the annals of modern science. According to conventional wisdom, he discovered the principles of a new science yet died before those principles were accepted. Mendel's failure to gain recognition in his own lifetime seems to enhance the romantic attraction of his story. Who can fail to be moved by the image of the painstaking experiments in the monastery garden that were ignored by all contemporaries?

Vitezslav Orel is head of the Mendelianum at the Moravian Museum in Brno, Austria, established in the monastery where Mendel worked, and is thus at the nerve-centre of international Mendel research. He is in an unrivalled position to provide a detailed account of Mendel's life and career. His biography is clearly destined to become the standard source, replacing old favourites such as Hugo Iltis's 1924 account. Orel is particularly concerned to trace Mendel's education, showing that he was by no means the untutored amateur of popular myth. On the contrary, his scientific education laid the foundations for his unique experiments with peas, in which he traced the transmission of hereditary characters. Orel also provides detailed insights into Mendel's other activities: his research on bees and on meteorology (for which he did gain some recognition) and his efforts as abbot of his monastery. Here we see the character of the man: efficient, enthusiastic and at a crucial stage willing to strike out into a new method of studying nature.

There is, of course, a detailed chapter outlining Mendel's classic experiments, published in 1866 . Considering the brevity of his paper, and the relative paucity of other written material left by Mendel, historians have come up with a surprising number of different interpretations of his intentions. Orel successfully out-manoeuvres both those who would turn Mendel into a pure empiricist and those who have suggested that he cheated in order to substantiate his preconceived hypothesis.

$\mathrm{He}$ is less effective, though, in dealing with the challenge offered by historians who argue that the story of Mendel's discovery is a myth created by the founders of genetics in the early twentieth century. It has been suggested that a careful reading of the 1866 paper shows that Mendel did not in fact propose the modern concept of paired characters linked to factors (genes) in the reproductive cells. In effect, the modern ideas were read into Mendel's paper by the rediscoverers (Karl Correns and Hugo de Vries in 1900, and later William Bateson). On this interpretation, however prescient the experimental demonstrations of character-transmission, Mendel's own real interest was the formation of hybrids, not the laws of heredity.

Orel certainly warns his readers that there have been such iconoclastic claims, but, as his subtitle indicates, his account is firmly within the orthodox tradition. His discussion of "Mendelian mythmaking" comes after his analysis of the experiments, an analysis that has already begged the question by translating the results into modern terms, diagrams and all. At one point Orel dismisses the revisionists as "hero-bashers". But historians of genetics as eminent as Robert Olby have argued that Mendel was not a Mendelian in the sense defined by his posthumous followers. Such warnings cannot be set aside quite so easily; we must acknowledge at least the possibility that the context of Mendel's own work differed substantially from that of the rediscoverers. Placing Mendel's work in its context means more than making a sympathetic study of his career; it requires a willingness to uncouple his key text from the layers of meaning read into it by later geneticists.

Orel's discussion of events following Mendel's death concentrates as much on the celebrations of his work as it does on the actual 'rediscovery'. One could hardly expect a biography of Mendel to spend too much time on later developments, but the question of how Mendel's own work was transformed by the rediscoverers is more fundamental. The iconoclasts are not suggesting that his work was without influence in 1900: whatever Mendel's own intentions, his demonstrations forced Correns, De Vries and Bateson to rethink their whole approach to heredity. It would become even more important to see Mendel's career in context if we thought that his insights were both crucial to later developments and proposed originally for a different purpose. The assumption that his work was 'modern' but ahead of its time hinders our ability to understand its original context. But perhaps this is a task for the historian, not the biographer. With its wealth of detail, Orel's account certainly moves the study of Mendel's life onto a new level.

Peter J. Bowler is in the Department of Social Anthropology, Queen's University of Belfast, Belfast BT7 1NN, UK. 